\title{
CONSOLIDAR SOCIABILIDADES, PAUTAR PLATAFORMAS DE TERRITORIALIZAÇÃO
}

CONSOLIDATING SOCIABILITIES, GUIDING TERRITORIALIZATION PLATFORMS

Marcelo Calderari Miguel ${ }^{1}$

Recebido: 22/08/2020

Aceito: 28/12/2020

\section{Entre Rio e Bahia, a presépio cidade}

Vitória é Conquista não apenas na Bahia. Vitória no Reino Unido foi majestade, rainha.

Ilha essa o Espírito Santo tornou capital. IDH sublinha veemente quinta melhor posição.

Toda humanizada é sol, presépio e lazer. Terceira melhor capital do Brasil para se viver.

Ovaciona o melhor capital humano reter. Oportuniza gestão de projeto e acessibilidade.

Rico clima tropical litorâneo dá lhe brio. Referência em cultura, turismo e gastronomia.

Ilustre lócus, inteligentemente conectado. Imanta viril educação, gestão e infraestrutura.

A urbe realça memorável ranking saúde. Avaliação da qualidade de vida é referendável.

\footnotetext{
1 Administrador e bibliotecário, Universidade Federal do Espírito Santo, Brasil. Pesquisador no Programa Institucional de Iniciação Científica e Tecnológica, Ufes, Brasil. https://brapci.inf.br/index.php/res/v/30539 Av. Princesa Isabel, 86, Centro, Vitória, Espírito Santo, 29010-360. E-mail: marcelo.miguel@edu.ufes.br
} 


\section{Ufes em bodas de ébano: no fechar das histórias escreve-se valores}

Autonomia didática, científica, administrativa e a magnífica financeira gestão.

Luta e avança nos canais científicos, tecnológicos, educacionais, e culturais.

Atua na calcada indissociabilidade ética e moral de suas pesquisas sociais.

Oportunizando ações sustentáveis no ensino, na pesquisa e na extensão.

Respeito reporta à justiça, à equidade e ao crítico pensamento.

Diversificada é a sua Carta de Serviços - que açula empreendedoras ações e propala:

Estudar na Ufes 'não tem preço. Tem valores!'. Isto posto, um manifesto para vida.

\section{Qualificada}

Universidade criativa

Educacional e cultural

Importante para comunidade e

Reduto de paz e celebração, buscando

Organização e ecossistemas de inovação social.

Zelo com a natureza e com a essência das parcerias de ensino, pesquisa e extensão.

Acessibilidade é um norteador, pilar das todas as suas atuações.

Referencial de qualidade, a autárquica instituição gera indicadores notáveis.

Avoca inovações múltiplas - evidências muitas, no aumento de sua internacionalização.

Única no internacional ranking Times Higher Education, realce impar no panorama capixaba.

Junta com o Hospital Universitário Cassiano Antonio Moraes o que há melhor na gestão e saúde.

Oferta ainda serviços de ponta: teatro, cinema, biblioteca, planetário, museus e galeria de arte. 


\title{
3 Penedo, Patrimônio Natural Paisagístico de Vitória
}

\author{
Forte Penedo, rochedo.
}

Medindo cerca de $133 \mathrm{~m}$ de altitude.

Quanta altitude, símbolo da baía de Vitória.

Tombado foi como patrimônio natural paisagístico.

Embeleza a vista daqueles que passam nesse estreito de Vitória.

Monumento natural de referência turística e geográfica do capixaba.

Jeitosa pedra é um maciço rochoso litorâneo, formação granítica e gnáissica.

Se Vila Velha localiza, em Vitória revela seu relevo forte ondulado e bem escarpado.

Às margens da Baía de Vitória esse maciço rochoso litorâneo é tenaz revelação e força!

Se o rochedo falasse, muita historia teria. Pode-se-ai dizer que é o guardião dessa baia. Conta-se que em dia de tempestade e de vazantes marés, horripilante gemidos dele saia. Descobriu-se tempos depois que era o barulho certeiro do aguaceiro batendo nas pedras. Tem essa majestade ainda uma bela cobertura vegetal, remanente vivo da atlântica mata. 


\section{A freira e o frade, outras histórias a contar, uma geografia a marcar}

Fé e pela igreja é proibido - tal amor entre freira e frade.

Religiosos da paixão - refreando que o amor mais bonito, é o que não se vive.

A convicta crença é sentir - nisso ambos se incumbiam de tal sentimento sufocar.

Deus orgulhoso de sacrifício - veio mesmo é desenhar...

$\mathbf{E}$ na rocha figuralmente registrou - ser humano é mais forte que as paixões!

Feliz é a atitude piedosa de quem reza - posição encurvada, num embuçar de orações... Rocha espetacular, arte na forma de frade e freira - sob uma manta bruma de respeito e retidão.

$\mathbf{E}$ isso, vem muito a calhar o rochedo entalhado - uma freira tímida e um frade honrando bênçãos.

Ideal e doutrinal trindade - portal de união: Itapemirim, Cachoeiro de Itapemirim e Vargem Alta.

Reforça o granito uma pura oração - a prece que vence o pecado e eterniza um granítico conjunto.

A lenda é o lúbrico apego - eis os 68 metros de altitude e formação, situado no distrito de Gruta. 


\section{No margear da vida, o alvor da alma}

Café, Vinho \& Licor.

Traga tudo meu amor.

Sou um tanto carecedor.

De um papinho ligeiro, de um leal companheiro, de alguém para me contrapor.

Vinho, Café \& Licor.

Não esqueça o sabor.

Busco tanto amargor.

Que venha um ser de papo faceiro, um leal cozinheiro, alguém que me dê ardor.

Vinho, Licor \& Café com fervor.

Traga tudo embaixador.

Busco tanto um pandeiro.

Que venha com papo roqueiro, um leal boiadeiro, alguém com muito humor.

Licor, Vinho \& Café com fervor.

Não se esqueça do embalador.

Sou um tanto cabreiro.

Tenho papinho candeeiro, sou um leal barqueiro, um exímio administrador.

Café, Licor \& Vinho, por favor.

Sou um tanto acolhedor.

Traga tudo diretor.

Alguém com papinho mineiro, um leal zagueiro, alguém com vigor.

Licor, Café \& Vinho, por favor.

Não se esqueça do calor.

Busco tanto um mercador.

Que venha com papo brejeiro, um leal tesoureiro, alguém para me transpor. 